\title{
Role of Small Grains in Adapting to Climate Change: Zvishavane District, Zimbabwe
}

\author{
Tendai Nciizah, Elinah Nciizah, Caroline Mubekaphi, and \\ Adornis D. Nciizah
}

\section{Contents}

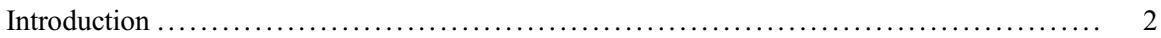

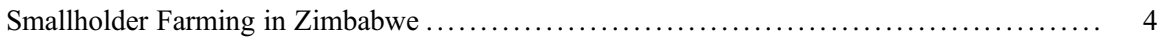

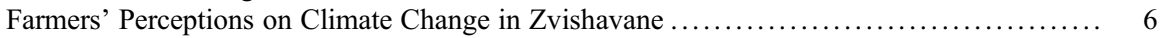

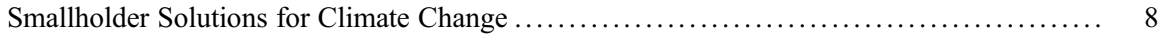

Characteristics and Impact of Small Grain Production on Climate Change Adaptation in

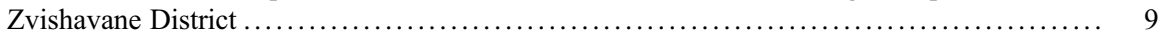

Perceived Barriers to Small Grain Production in Zvishavane .......................... 11

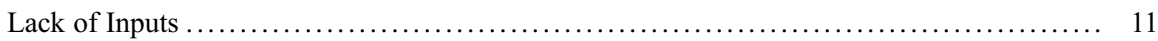

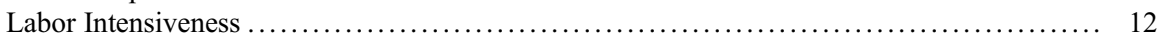

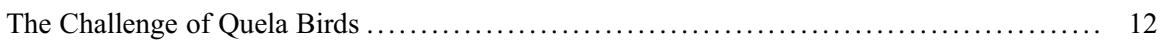

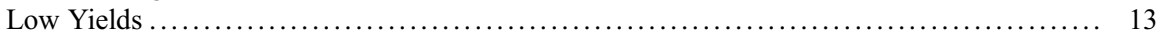

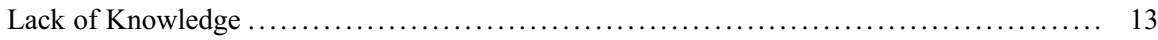

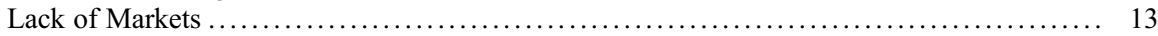

This chapter was previously published non-open access with exclusive rights reserved by the Publisher. It has been changed retrospectively to open access under a CC BY 4.0 license and the copyright holder is "The Author(s)". For further details, please see the license information at the end of the chapter.

\section{T. Nciizah}

Department of Sociology, Rhodes University, Makhanda, South Africa

E. Nciizah

Department of Development Studies, Zvishavane Campus, Midlands State University,

Zvishavane, Zimbabwe

e-mail: nciizahe@staff.msu.ac.zw

C. Mubekaphi

School of Agricultural, Earth and Environmental Sciences, University of KwaZulu-Natal, Scottsville, South Africa
A. D. Nciizah $(\square)$
Soil Science, Agricultural Research Council - Institute for Soil, Climate and Water, Pretoria, South Africa
e-mail: nciizaha@arc.agric.za 


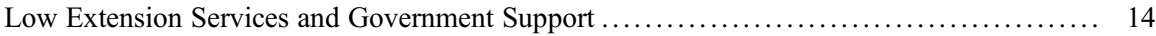

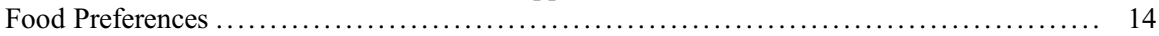

Interventions to Overcome the Barriers to Small Grains Adoption ..................... 15

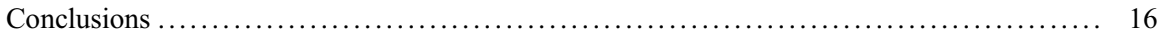

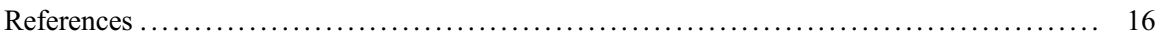

\section{Abstract}

Climate change has become one of the most profound threats to smallholder agriculture in semi-arid and arid areas. Farmers in this sector are especially vulnerable to climate change due to reliance on rain-fed agriculture, limited access to capital and technology among other challenges. While several potential adaptation options exist, many barriers hinder effective adoption of these practices, hence production in marginal areas remains very low. This chapter discusses crop adaptation through the adoption of small grains in Zvishavane rural, a semi-arid area in Zimbabwe. Small grains are conducive in hot areas; their drought-tolerant nature enables them to thrive in marginal areas making them an appropriate strategy in responding to climate change. However, several production and policy challenges associated with small grain production hinder their adoption by farmers. In view of this, this chapter discusses the potential of small grains as an adaptation strategy to climate change in Zvishavane District, Zimbabwe, and addresses potential challenges and opportunities for increased adoption and future research. The review showed that farmers in Zvishavane have perceived climate change due to noticeable changes in rainfall and temperature patterns in the past years. Despite small grain production being the best strategy due to drought and high temperature tolerance, an insignificant number of Zvishavane farmers is involved in small grain production. This is due to numerous barriers such as high labor demand associated with small grain production, the challenge posed by the quelea birds, food preferences, low markets, and low extension services and government support. It is therefore necessary to encourage adoption of small grains by developing improved varieties, adoption of climate smart agricultural practices, improved technical support, and access to markets among other interventions.

\section{Keywords}

Adaptation $\cdot$ Climate change $\cdot$ Mitigation semi-arid areas $\cdot$ Small grain production $\cdot$ Smallholder farmers $\cdot$ Vulnerability

\section{Introduction}

Climate change has become one of the major threats to rain-fed agriculture resulting in major drawbacks in agricultural production and food security. IPCC (2007) notes that climate change has significantly modified rainfall and temperature patterns in many parts of the world. There is strong evidence of erratic rainfall and a noticeable shortening of the agricultural seasons worsened by higher ambient temperatures resulting in perennial crop failure and frequent droughts across the world (Jerie and 
Ndabaningi 2011). The adverse effects of climate change are more pronounced within the smallholder agricultural sector in Africa, including Zimbabwe, compared to the more technologically advanced and high resource input commercial sector. Generally, smallholder agriculture is practiced by families or households using only, or mostly, family labor and deriving from that work a large but variable share of their income, in kind or in cash (HLPE 2013). It therefore follows that the livelihoods of smallholder farmers largely depend on agriculture and are particularly vulnerable to several hazards. Consequently, if changing climatic conditions continue unabated, traditional rain-fed agricultural systems will become increasingly unsustainable with severe food security implications.

Temperature in the sub-Saharan Africa region is predicted to increase by between $1{ }^{\circ} \mathrm{C}$ and $2.5^{\circ} \mathrm{C}$ by 2030 , which will ultimately result in yield losses of up to $20 \%$ by the 2050s depending on region (IPCC 2007). Consistent with regional data, Zimbabwe's annual mean surface temperature has warmed by about $0.4{ }^{\circ} \mathrm{C}$ from 1900 to 2000 with the period from 1980 to date being the warmest on record. Moreover, the timing and amount of rainfall received are becoming increasingly uncertain, with current data showing that during the last 30 years there has been frequent droughts and rainfall has significantly decreased with shorter seasons (GoZ 2014). Consequently, the Food and Agriculture Organization (FAO 2007) observed that the crop failures have been a result of early termination of the rains in most seasons or low rainfalls in Zimbabwe, especially in semi-arid areas. Gukurume (2013) perceived that climate change in countries like Zimbabwe has presented insurmountable challenges to the agricultural sector as well as agricultural sustainability. Droughts, floods, increased temperature, increased rainfall variability, and declining precipitation negatively affected agriculture in Zimbabwe, with other districts recording almost nothing in terms of output (Zimbabwe Agricultural Sector survey 2019). The 2018/19 cropping season was marked by a late onset of rains, which resulted in abnormally dry conditions, affecting agricultural activities such as land preparation and planting (IPC Zimbabwe 2019).

The effects of climate change in Zimbabwe are exacerbated by the concentration of most smallholder farmers in marginal soils in semi-arid and arid areas located in the natural region IV and $\mathrm{V}$, which makes them more vulnerable to climate change due to their low adaptive capacity. High temperature and erratic rainfall have resulted in constant low yields of the preferred maize staple in the country. Maize is not a drought-tolerant crop; hence, it is highly sensitive to harsh environmental conditions, which negatively affect the yield (Muzerengi and Tirivangasi 2019). There is therefore a need to implement adaptation and mitigation strategies that will ensure resilience to climate change. Adaptation has the potential to reduce adverse impacts of climate change and to enhance beneficial impacts and hence reduce vulnerability both in the short and long term (IPCC 2001). There are several adaptation interventions that have been suggested for smallholder farmers including but not limited to crop relocation, adjustment of planting dates, and crop variety; improved land management, e.g., erosion control and soil protection incorporating agroforestry (IPCC 2007). However, due to the vulnerability of maize to drought, there is the need to move away from the production of maize and look for alternative crops that thrive under changing climatic conditions. Sharma et al. (2002) highlighted that 
there is an urgent need to focus on improving crops relevant to the smallholder farmers and poor consumers in the semi-arid areas. This chapter focuses on the adoption of small grain crops, which have been shown to thrive under harsh conditions, as one of the most viable strategies that must be consistently implemented in such semi-arid and arid areas as Zvishavane District in Zimbabwe, which are facing significant production challenges due to climate change. Zvishavane District has experienced recurrent droughts, inconsistence rainfall, and is consequently one of the districts that constantly faces food insecurity in the country. According to Mawere et al. (2013), for the past two decades, Zvishavane, among others in Zimbabwe and beyond, has witnessed pronounced increases in temperature, recurrent droughts, and unpredictable rainfall patterns, yet people mainly depend on rain-fed agriculture and natural resources for their livelihoods. This chapter discusses the potential of small grains as an adaptation strategy to climate change in Zvishavane District, Zimbabwe, and addresses potential challenges and opportunities for increased adoption and future research. The chapter will answer the following questions:

(i) What are the Zvishavane farmers' perceptions on climate change?

(ii) To what extent are farmers in Zvishavane adopting small grains?

(iii) What are potential barriers/challenges and opportunities for increased adoption of small grain crops in Zvishavane District?

\section{Smallholder Farming in Zimbabwe}

The smallholder sector is known for its small farms, mostly less than 2 hectares that are labor-intensive, uses traditional production techniques, and often lack institutional capacity and support (Louw 2013). The definition of smallholder farmer depends on the country; for instance, in Zimbabwe, smallholder farmers are typically farmers who are food insecure, predominantly in low rainfall areas who depend on rain-fed agriculture. Their reliance on rainfall for agricultural production exposes them to the risks posed by climate change. Smallholder farmers face challenges such as lack of infrastructure, reliance on rain-fed systems, highly degraded soils, a variety of chronic crop-affecting diseases, tough economic conditions due to poorly functioning markets, and limited access to credit, knowledge, and lack of farming skills (Mutekwa 2009). Lack of assets, information, and access to services deters smallholder farmers' involvement in possibly profitable markets. Moreover, most smallholder farmers are confronted with labor limitations as a result of HIV/AIDS, chronic illness, poverty, and illiteracy. Furthermore, smallholder farmers lack adequate knowledge, which leads to poor selection of cultivars, fertilizer application, and delayed planting of crops. As a result, the crop yields are negatively impacted. Worse still they are far from road networks to transport inputs, produce, and also access information and have a tendency to use inefficient modes of transport such as animals. In Zimbabwe there is nonexistence of investment in infrastructure, for instance, roads, storage, and market facilities and this handicap the potential role of smallholder farmers. This problem is 
not only common in Zimbabwe but the rest of Africa as well as most African government policies are unsuitable and inconsistent, and do not provide an enabling environment for the development of the small grains sector.

Mutasa (2011) highlighted the reasons below as challenges or factors that farmers are faced with that also increase farmers' vulnerability to climate change.

(a) Poor soil moisture holding capacity

(b) Lack of necessary farming knowledge

(c) Lack of draught power

(d) Difficulties accessing the appropriate inputs on time

(e) Inadequate farming space

(f) Poor rains and/poor rainfall distribution

(g) Communities' failure to fully recover from previous drought disasters

(h) Poor fiscal policies resulting in hyperinflation and inaccessibility to cash especially after the dollarization of the economy

(i) Poor governance evidenced by the suspension of humanitarian organizations' operations when they were greatly needed

(j) Politicization of food assistance and input schemes (benefitting only supporters of a particular party)

(k) Corruption associated with input facilities

(l) Communities' focus on maize production at the expense of other traditional crops

(m) Depletion of human resources and sources of income due to brain drain, HIV, and AIDS and other epidemics

All the above mentioned challenges affect their competitiveness and it leads to them having high transport costs to sell their products in the market and buy inputs. In addition, smallholder farmers face challenges in accessing markets due to inadequate infrastructure, low productivity levels, inconsistencies in supply, and low quality owing to poor post-harvest practices (FAO). Smallholder farmers do not make much income as they lack a reliable market and as a result sell their produce at their farm gates or local market where they sell below market value (Aaron 2012). They tend to be inconsistent in production due to lack of bargaining power and inability to reliably supply their products fresh to markets (Aaron 2012). Harvested crops are threatened by insects such as weevils, larvae, termites, and rodents such as rats; these insects may be present in the grains making it less marketable. Some of the pests are attributed to lack of storage facilities as some smallholder farmers store grain in their sleeping quarters whereas those who have structures tend to be in very poor conditions and hence cannot hinder pest attack.

Changing climatic conditions have become one of the major challenges affecting smallholder farmers in Zimbabwe and the rest of the world. In 2016 and 2017, Zimbabwe had a drought, which was aggravated by the impact of El Niño. Smallholder farmers tend to suffer from these disasters due to their low adaptive capacity, which increase their vulnerability, hence they have no means of recovering from the effect this has on their livelihoods. Most smallholder farmers have a tendency to recover by selling their productive assets, such as their livestock or land. Moreover, 
these persistent droughts, which have taken place over the past few years due to changes in climate, continue to erode maize yields. For instance, maize yields have been reduced to less than 1.5 ton $\mathrm{ha}^{-1}$ against a potential yield of more than 5 tons $\mathrm{ha}^{-1}$ (de Jager et al. 2001).

Semi-arid and arid regions like Zvishavane district have some of the worst affected farmers in Zimbabwe. Zvishavane is a district in Zimbabwe bordered by Mberengwa, Chivi, and Shurugwi districts. The mean annual temperature is $20{ }^{\circ} \mathrm{C}$ although high temperatures of up to $30{ }^{\circ} \mathrm{C}$ have been recorded during the hot months from October to December (Nciizah 2014). The area receives an annual rainfall of about 450-600 mm placing it in region IV but during droughts there can be just $250 \mathrm{~mm}$ of rain (Oakland Institute Undated). According to the OCHA report (2012), region IV is subject to periodic seasonal droughts and severe dry spells during the rainy seasons, and crops can only be intensified by growing of drought-tolerant crops. Natural farming regions are a classification of the agricultural potential of the country, from natural region $1(>1000 \mathrm{~mm}$ per annum), which represents high altitude wet areas to natural farming region $\mathrm{V}$, which receives low and erratic rainfall averaging $550 \mathrm{~mm}$ per annum (Mugabe et al. 2007). The table below shows the agroecological regions in Zimbabwe and their characteristics.

Rainfall in Zvishavane has been erratic such that in some areas like Mazvihwa, rain-fed agriculture has become unreliable, worsened by droughts that have gripped the country (Nciizah 2014). Despite the hot climatic condition of the district, agriculture remains the main source of livelihoods (Mugiya and Hofisi 2017). Just like all areas in Zimbabwe, the main crop grown by smallholder farmers in Zvishavane is maize. Droughts and little rainfall in the district have led to low maize crop yields leading to food insecurity to be high in the area. According to ZimVac (2015), Zvishavane was one of the districts with the highest food insecurity levels with $42.2 \%$. In 2016, the level went up with $50 \%$ households being food insecure, hence the need for adaptation and mitigation measures in smallholder farming areas (ZimVac 2016). Adaptation measures include adjustment of planting dates and crop variety, crop relocation among others. However, one of the most recommended approach is the growing of drought-tolerant crops such as small grains (Gukurume 2013; Muzerengi and Tirivangasi 2019; Musara et al. 2019). Adoption of small grains becomes a crucial necessity that must be embraced by households in the area. Small grains grown in the area are sorghum and millet, with finger millet being more common than pearl millet (Nciizah 2014).

\section{Farmers' Perceptions on Climate Change in Zvishavane}

Smallholder farmers in Zvishavane perceive climate change using two variables, which are temperature and precipitation paying attention to events that have been occurring in the area for the past 10 to 20 years. Perceiving that climate is changing is crucial as it leads to adaptation. According to Jiri et al. (2015), perceptions help to shape smallholder farmers' coping and adaptation strategies. Adaptation is a twostep process, which requires that farmers first notice that the climate has changed and 
then secondly, implement adaptation strategies. Farmers' ability to acknowledge the importance of adapting therefore largely depends on whether they have observed that there is climate change in the first place (Nciizah 2019). Most studies have shown that farmers who perceive that the climate is changing in line with the actual climate change records are most likely to adapt to climate change (Jiri et al. 2015). Simba et al. (2012) concurs that the most crucial element in spearheading adaptation options is for farmers to perceive climate change. Such farmers who perceive that the climate has changed, for instance, will be able to realize a sharp decrease in maize yields. Numerous studies have been done on farmers' awareness on climate change (Gbetibouo 2009). A study by Okonya et al. (2013) in Uganda showed that $99 \%$ of all households interviewed had observed a change in the climate in the last 10 years.

The greatest concern for farmers in Zvishavane is the drastic changes in rainfall patterns and temperature. This is confirmed by the records from meteorological centers. A study by Jiri et al. (2015) also confirmed the decline in rainfall and an increase in temperatures over the years. Similarly, Mutekwa (2009) showed that farmers in Zvishavane were mainly concerned with precipitation and temperaturerelated weather events, as the ones that are a real concern in relation to their agricultural activities. There are now more experiences in dry spells and cold spells. Murowa ward in Zvishavane is already a drought prone area and farmers indicated that dry spells have become more frequent and devastating in recent years (Mutekwa 2009). Farmers in the area now experience extremely high temperatures and very low rainfall. Maddison (2006) also reported a similar trend of increasing temperatures in his study in 11 African countries. Another concern for smallholder farmers in Zvishavane is the changing onset of the rainfall season, which was confirmed by a study done by Mawere et al. (2013) in Zvishavane and Chivi. The study revealed that the climatic conditions that have prevailed for the past 5 years or so in agro ecological regions IV and V were very hot with dry conditions. There was rainfall below average (300 $\mathrm{mm}$ per annum) with poor distribution giving high chances of dry spells. In the past, the area used to receive three groups of rainfall, which are Bumharitsva (August), Hukurahundi (September), and Munakamwe (November) per year. Now they only receive one rainy season (munakamwe), which is also not predictable (Mawere et al. 2013). In addition, the farmers used to receive the last rains in March but this is no longer the case. The rains are no longer predictable as they can come very late and end early, something that has proved to be challenging to the farmers.

In the same study by Mawere et al. (2013), it was discovered that $96 \%$ of the respondents acknowledged their awareness of the changes in their local weather pattern and climate change. Many smallolder farmers in the study perceived the following as indicators: less and less rainfall leading to droughts, dwindling farming seasons, unpredictable weather patterns, high temperatures, decrease in livestock and crop production, low fruit production of wild fruit trees, and extinction of some area-specific species. Many smallholder farmers in Zvishavane have noted that although the coldest month of the year in Zimbabwe is June, it has been becoming less cold and the hottest month and October has become hotter than the previous years. It has also become apparent for most farmers that precipitation has been 
declining for years with more frequent drought occurrences. Drought occurrences have largely contributed to low yields and drastic effects on livestock production (Jiri et al. 2015). Farmers in Zvishavane have perceived inconsistent rainfall patterns and arid conditions in the area, which have led to the perennial flop of maize production (The Chronicle 2020). A survey done by International Crops Research Institute for the Semi-Arid Tropics (ICRISAT) noted that most farmers in Mberengwa and Zvishavane have been realizing very low yields from maize and other crops because of the effects of climate change (The Chronicle 2020).

Wetlands in Zvishavane have also declined over the years. Farmers in Zvishavane pointed out that their cattle used to drink water at wells and wetlands around the area but the wetlands are no longer there and they have to fetch water from distant places (Mawere et al. 2013). They also add that mountains in the area used to have wind storms signifying coming of heavy rains. This however no longer happens. Storms used to signify rainfall as well as animals such as ducks, baboons, rain bird-blue bird. Such animals are no longer existent as they have moved to other areas in search of food (Mawere et al. 2013).

\section{Smallholder Solutions for Climate Change}

Climate change has rendered Zimbabwe's region IV a non-maize producing zone due to climate shocks, a situation that promotes food insecurity (Mugiya and Hofisi 2017). This has left the majority of people in semi-arid areas food insecure, which calls for the need for adaptation. Given the reliance of most people in Zimbabwe on rain-fed agriculture, it becomes pertinent to identify solutions that can be implemented in order to deal with the insurmountable challenges posed by climate change. There are a couple of solutions that have been identified in some studies inclusive of conservation agriculture, irrigation, and gardening. A study by Mutasa (2011) showed that farmers in Buhera and Chikomba districts have incorporated certain strategies to address droughts that are prevalent in the area. The strategies are inclusive of early cropping, staggered cropping, dry planting, and planting crops with a short maturity life. This study recommends the production of small grains in semi-arid areas like Zvishavane. Small grain production will likely curtail the numerous challenges faced by farmers in Zvishavane given the advantages posed by small grains. Small grains have always been there and are not new as they were there before the introduction of maize; they are an indigenous African crop with more nutritional benefits than maize.

Several studies have looked at how small grains can lead to food security especially in semi-arid areas (Leuschner and Manthe 1996; FAO 2006; Mukarumbwa and Mushunje 2010). They highlight the numerous advantages associated with small grain production. Among such advantages are their nutritious value, drought resistance, and how they can be stored for longer periods as compared to maize. Leuschner and Manthe (1996) pointed out that sorghum and millet are some of the most important cereal crops for communal farmers in Natural Regions $1 \mathrm{~V}$ and $\mathrm{V}$ of Zimbabwe. Their study showed that in regions with low and erratic 
rainfall like Zimbabwe's Natural Regions $1 \mathrm{~V}$ and $\mathrm{V}$, small grains have the potential of stabilizing household food security. In a study by Taylor (2003), sorghum and millet are vitally important cereals for the maintenance of food security in Africa. FAO (2006) also supports that small grains are the answer to chronic food shortages to rural communities who reside in semi-arid regions, especially of the sub Saharan region.

\section{Characteristics and Impact of Small Grain Production on Climate Change Adaptation in Zvishavane District}

As alluded to earlier, more than 475 million smallholder farmers across the globe cultivate less than 2 ha of land each (Lowder et al. 2016) on poor and marginal land with lack of access to technical or financial support that could help them invest in more climate-resilient agriculture (Morton 2007). These challenges are exacerbated by the effects of climate change, hence the need for appropriate adaptive and mitigation measure. Due to these challenges, smallholder farmers in semi-arid to arid areas continue to achieve very low yields. Growing small grains becomes an adaptation measure that smallholder farmers in areas prone to water and heat stress need to implement instead of maize, which is highly susceptible to water stress. Although maize is the preferred grain crop in Zvishavane and the rest of Zimbabwe, it is frequently written-off due to frequent droughts (Nciizah 2014) resulting in maize yields below 1 ton/ha. Consequently, small grain crops like millet and sorghum, which can better withstand drought conditions and offer more stable yields in the long term, are a better choice (Nciizah 2014; ICRISAT 2015). Small grains, particularly sorghum, adapt well to harsh climates and thus can grow in dry conditions due to their ability to tolerate heat, salt, and water stress, which makes them an ideal crop for semi-arid and arid areas (ICRISAT 2015).

There has been a conscious drive by the Government of Zimbabwe (GoZ) to urge farmers in arid and semi-arid to opt for small grain as a coping mechanism to climate change as evidenced by the increase in programs promoting sorghum production (GoZ 2014). The government of Zimbabwe has been working with international organizations such as FAO and ICRISAT to assist farmers in the country's marginal areas to focus more on the production of small grains such as sorghum and millet in order to counter poor yield and hence hunger. In Zimbabwe, small grains (sorghum, pearl, and finger millet) rank second after maize and consequently play a vital role in ensuring food security and nutrition (UNDP 2018b).

Droughts and dry spells have made smallholder farmers in Zvishavane to be expected to rely on irrigation schemes if they want to produce good maize yields. Unfortunately most of these farmers do not have the financial capacity to purchase the required equipment and the much needed fertilizers (Nciizah 2014). It is therefore vital for these farmers to concentrate more on small grain production compared to maize. Most of the farmers in the area are still concentrating on maize production with only a few household producing small grains. They still follow the norm of the country whereby maize is the mainstay crop even in drier areas where small grains 
can be produced economically and sustainably (Rukuni et al. 2006). However, this needs to change as maize production is no longer conducive for semi-arid areas that are constantly facing droughts and erratic rainfall. Recently, Zvishavane faced a drought in the 2019/2020 season leading to crop failure. In such circumstances, full adoption of small grain adoption becomes a necessity if the area is to avoid zero crop yields. This is mainly because small grains have characteristics and properties that allow them to thrive in areas like Zvishavane.

Sorghum and millet are important traditional cereal crops in Africa (Chisi Undated). Notably these cereals are indigenous to the African continent (Musara et al. 2019), making them well adapted to the African semi-arid areas (Taylor 2003). These small grains have become favored because of their good adaptation to hard environments and their good yield of production. The grains are drought resistant as compared to maize, making them to thrive in areas that are hot and have limited rainfall. Water requirements over the growing period average $400 \mathrm{~mm}$ for sorghum and $300-350 \mathrm{~mm}$ for millet as compared to $500 \mathrm{~mm}$ that is required for maize (Orr et al. 2016). Hence, they are genetically adapted to drylands that face little and irregular rainfall, drought, and high temperatures than other cereals like maize. This makes them to be able to give some yields in years of low rainfall, especially when grown in a multi-cropped system, whereas maize will be a complete failure (Muzerengi and Tirivangasi 2019).

Sorghum and millet also have deeper roots than maize and can withstand higher temperatures without damage to the crop (Orr et al. 2016). Bang and Sitango (2003) point out that small grains are generally the most drought-tolerant cereal grain crops as they require little input during growth. They bring more nutritional value to people's diet compared to cereals like maize. Dube (2008) posits that some of the advantages of small grains like sorghum and millet over maize include the following: a smaller amount of flour is needed to cook the main meal compared to maize, and a meal cooked from small grains satisfies hunger for a longer period and gives more energy (which is especially important for persons who do heavy manual labor like farmers).

Specifically, looking at finger millet, it can be observed that the crop has valuable properties that make it more beneficial to grow in the semi-arid of Zvishavane. The cereal is drought resistance in nature, has high nutritional content and has the ability to produce with few inputs. Finger millet is a nutritious crop providing proteins, carbohydrates, minerals, and amino acids, especially methionine, which is lacking in the diets of numerous poor people who live on starchy foods (Bhatt et al. 2003). This goes the same with sorghum, which remains important for sustainability of smallholder farmers' subsistence, social and economic livelihoods in semi-arid areas (Musara et al. 2019). Sorghum grain contains $11.3 \%$ protein, 3.3\% fat, and 56 73\% starch (National Research Council, 1996). It is relatively rich in iron, zinc, phosphorus, and B-complex vitamins. Tannins, found particularly in red-grained types, contain antioxidants that protect against cell damage, a major cause of diseases and aging (National Research Council, 1996). Thus, sorghum and millet have the capability of providing the nutritional value that can boost the immune system of people particularly poor families. They both have more health nutrients 
compared to maize, wheat, and rice and they improve the physical health of the elderly, the sick, children, and pregnant and nursing women. Another advantage of sorghum and finger millet maize is that they have a long shelf storage life as they can be stored for about 5 years compared to maize, which is only stored for about 2 years. Hence, they become conducive in Zvishavane, a place that is facing consistence drought and erratic rainfalls.

Although small grains are mostly suitable for Zvishavane, research conducted in the area shows that most smallholder farmers are still reluctant to fully adopt the grains. Mawere et al. (2013) in a study in Zvishavane stated that in as much as farmers reported that small grain crops performed much better than maize, most farmers still preferred growing maize. Similarly, Nciizah (2014) observed that an insignificant number of farmers were cultivating small grains in the area. Mugiya and Hofisi (2017) reported that while small grain crops prove to be a viable option to boost production in the background of climate change vulnerability, people in Zvishavane were not adopting such varieties enthusiastically, as adopting such varieties threatened their food preference. Hence, in Zvishavane, a significant number of households still prefer maize over small grain production. There are a number of barriers that have affected small grain production in Zvishavane. This has made the area to be consistently food insecure as smallholder farmers still grapple with inadequate yields.

\section{Perceived Barriers to Small Grain Production in Zvishavane}

Despite the advantages associated with small grains, small grain production remains low with only a few farmers producing these around Zimbabwe and specifically in Zvishavane. Studies done in Zimbabwe have shown that small grain production continue to decline (Gukurume 2013). The production of small grains has been very low in Zvishavane and the decline in small grain production is due to a number of barriers, which are central to this chapter. As indicated by smallholder famers in Zvishavane the major barriers to small holder production are labor constraints associated with small grain production, the challenge of birds (quelea birds), lack of inputs, and challenges associated with storage among other aspects. Studies have shown that small grain production is a good adaptive strategy, but is difficult to implement given the problems associated with the production of the crops. All barriers central to small grain production in Zvishavane are discussed below:

\section{Lack of Inputs}

UNDP (2018a) carried out a study on the barriers to small grain production. Their study showed that there are constraints in accessing inputs that limits the uptake of small grains. Overall, the results of the study showed that there is overreliance of farmers on untreated seed, evidencing inefficiency of the formal market. The study confirmed that treated and packed seed is not readily available in local markets or 
alternatively, if available, farmers do not afford the improved seed. This is the same case as what is transpiring in Zvishavane. There is limited access to small grain seeds, which reduces its production. In most cases, farmers end up using untreated seed, which largely contributes to poor yields.

While improved varieties of seeds have been released by NGOs in Zvishavane District, the seeds of these small grains are not readily available from the various seed producers (Nciizah 2014). Whether farmers in Zvishavane want to produce small grains or not, their choices are affected by limited seeds. Christian Care, a nongovernmental organization (NGO) operating in Zvishavane, has distributed seeds to farmers but with limited stock, which has resulted in few farmers accessing it. In addition, given the limited seed stock of small grains and the easier accessibility of maize seeds most farmers end up preferring maize. Mugiya and Hofisi (2017) cited that in Zvishavane there is too much politicization of programs geared to boost productivity among small-scale farmers. Farmers in the area revealed that farm inputs (inclusive of seeds), which are meant to benefit smallholder farmers, are usually diverted for political initiatives impacting negatively on small grain production. In most cases farmers in Zvishavane end up planting sorghum seeds that they saved from their yield (Mugiya and Hofisi 2017). Most of these seeds are of very low quality, which impacts heavily yield.

\section{Labor Intensiveness}

The cultivation of small grains is extremely laborious, from land preparation, weeding, bird scaring to harvesting and grain processing. Most farmers in the area rely on manual production methods, which explains why labor intensiveness is a major concern. Nciizah (2014) noted that $95 \%$ of farmers in Zvishavane pointed to the labor intensiveness associated with small grain production as a very significant challenge. The study also showed how weeding is made more challenging by the similarities that exist between the weed "Eleusine Indica" and finger millet. The two are so similar that in most cases one might end up removing the crop and leaving the weed. There is also so much labor associated with harvesting the small grains given that the seeds are too small to handle and so much is done manually. Because the seeds are small it takes skill and much effort to mill finger millet (Nciizah 2014; UNDP 2018a). Farmers also mentioned the labor demands associated with processing of small grains as one of the limiting factors. Farmers in the study mentioned how processing of small grains is laborious as it involves threshing and winnowing, which is also done manually.

\section{The Challenge of Quela Birds}

Even though small grains are generally tolerant to diseases there is a huge challenge of damage by quela birds. Like in most studies (Nciizah 2014; UNDP 2018a), birds and animals are the major challenges in small grain production. According to 
Nciizah (2019), the birds are attracted by the grain of the crops as the grains are exposed unlike those of maize, which is covered by leaves. Chasing birds is highly regarded as a strenuous activity that most farmers cannot embark on. Farmers in Zvishavane prefer producing maize as maize is prone to attacks by baboons and wild pigs, which are easier to scare away than birds which attack the crop in large numbers and are difficult to chase away (Nciizah 2014).

\section{Low Yields}

In Zimbabwe, production of maize continues to dominate in the country's semi-arid regions as compared to small grains (Sukume et al. 2000). The lower productivity associated with small grains makes them very unattractive to communal farmers in semi-arid areas. Small grains also require large farm size, which is out of the reach for most farmers in Zvishavane. Given the limited farm size in most places in Zvishavane, most farmers then prefer producing maize. A few of those who produce small grains have large land size and can also provide labor required to produce these. Some studies have also discovered that small grains do not yield much crop residue as compared to maize, resulting in most farmers preferring maize production. According to Mapfumo et al. (2005), maize production provides crop residue for livestock, which the livestock largely depend on for survival during winter.

\section{Lack of Knowledge}

Despite the evidently dismal performance of maize in the area as a result of the effects of climate change, most farmers have for years been disregarding and fiercely resisting advice from agricultural experts to plant small grains (The Chronicle 2020). Research has shown that people tend to be largely ill-informed about small grain production. Many farmers in Zvishavane ignored the calls to adopt small grain production and in many instances continued to produce maize despite the realization that they are likely to get very low yields due to drought (Nciizah 2014). This is largely attributed to taste preferences and the low yields associated with small grains. Due to unawareness and lack of prioritization of small grains, most farmers end up cultivating small grains in their worst part of arable land, which heavily impacts production yields.

\section{Lack of Markets}

It has been found out that when it comes to selling small grains, it has a very low market as people prefer other agricultural produce like maize. This is also confirmed by a study done by FAO (1996), which explains that as incomes rise, consumers tend to purchase wheat, rice, and, in some cases, maize, rather than traditional coarse grains. This has resulted in farmers viewing small grains as having lower earnings 
than other crops. Nciizah (2014) showed that one major disadvantage of small grains cited by Zvishavane farmers is the limited marketing opportunities. In the study farmers complained about the absence of a ready market for small grains. Farmers in Zvishavane do not rely on the Zimbabwe Grain Marketing Board (GMB) to buy small grains. According to Mugiya and Hofisi (2017), farmers complained that the GMB normally delays to pay farmers, a situation which further complicates their adaptation, as their purchasing power remains poor.

\section{Low Extension Services and Government Support}

Mukarumbwa and Mushunje (2010), show that small grain production has been negatively affected by inadequate government support. Research has shown that sorghum and millet are the most drought-tolerant cereal grain crops suitable in semiarid regions (Taylor et al. 2006). The agricultural extension services department (AGRITEX) and the Department of Meteorological Services have extensively been incapacitated as a result of the country's economic and political challenges over the past decades that resulted in brain drain of skilled staff (Mutasa 2011). This has had a negative impact on farmers' production capacity and delivery of information about appropriate seeds and production technology. Mukarumbwa and Mushunje (2010) in their study indicated that inadequate government support to promote small grain production has led to low productivity of these small grains. Mugiya and Hofisi (2017) indicated that NGOs in Zvishavane are allegedly accused of imposing programs on small-scale farmers. The study also revealed that this also applies to government officials like extension officers. Extension officers believe that smallscale farmers are rigid and thus end up forcing farmers to adopt small grains. The farmers end up facing a challenge as their perceptions end up being ignored.

\section{Food Preferences}

A significant production constraint toward small grain production is food preferences. Most Zvishavane farmers significantly prefer maize due to taste preferences as compared to small grains. Mugiya and Hofisi (2017) reported that while small grain crops prove to be a viable option to boost production in Zvishavane in light of climate change, most farmers are not adopting small grains enthusiastically as it threatens their food preference. Such preferences affect the overall production of small grains. There remains a strong inclination to maize production as compared to small grain production. Maize is easily processed compared to small grains, which makes maize widely accepted. Jones (2011) pointed out food taste, media, and education as influential to people's food preference. Mugiya and Hofisi (2017) also indicated that children prefer maize to millet and sorghum. Food security in Zvishavane has been hindered due to farmers' rejection to produce small grains. 


\section{Interventions to Overcome the Barriers to Small Grains Adoption}

Despite the huge potential of small grain crops to provide a viable adaptation mechanism to climate change, adoption among smallholder farmers remains disappointingly low due to the barriers addressed above. There is need for practical solutions from all stakeholders that will make the crop attractive for smallholder farmers in drought prone regions such as Zvishavane District. A comprehensive review by UNDP (2018b) on emerging solutions to small grains value chains in Zimbabwe identified the following interventions;

(i) Availing improved varieties

(ii) Improved processing methods and equipment

(iii) Improved post-harvest management

(iv) Improved access to markets for both inputs and outputs

These interventions are likely to make small grain crops more attractive for smallholder farmers. For instance, Musara and Musemwa (2020) showed that the allocation of more land toward improved sorghum varieties by smallholder farmers resulted in improved food diversity and food access. Moreover, improved varieties are likely to be more resilient to elevated temperature and low rainfall conditions due to climate change. However, it is necessary for stakeholders to increase funding for the development of improved small grains varieties, which currently lags behind of maize. Nevertheless, it is important that breeders, seed companies, seeds suppliers, processors, and retailers work closely with smallholder farmers to effectively understand and incorporate farmers' preferences as the end users.

It is also important to note that while small grains like sorghum perform comparatively better than maize under harsh conditions, unfavorable soil conditions, extremes in weather, pests, and poor management practices negatively affect yield. Consequently, it is important to complement improved varieties with sustainable cropping practices. One of the most widely recommended approaches is climate smart agriculture (CSA), which entails agricultural practices that concurrently increase productivity, strengthens resilience to climate change (adaptation), reduces/removes GHGs (mitigation), and contributes to achieving food security and development objectives (FAO 2010). Examples of such practices include conservation agriculture, legume intercropping, agroforestry, organic agriculture, and improved pest, water, and nutrient management. These practices significantly improve soil health, which ultimately improves crop productivity. Improved cropping practices have a potential to improve yields, which may in turn increase adoption of small grains. An increase in the adoption of the crop may in turn make seed production more attractive for established seed companies, who currently do not see the benefit of producing small grain seed due to low sales. However, for farmers to adopt these sustainable agricultural practices, there is a need to strengthen technical support services. Poor technology as well is generally one of the most prevalent challenges to agricultural production and uptake of new technology in smallholder farming areas. 


\section{Conclusions}

The Chapter examined the role played by small grains in adapting to climate change in Zvishavane. Farmers in Zvishavane have perceived climate change as they have noticed changes in rainfall and temperature patterns in the past years. Such perceptions have been helpful in assisting many farmers to realize the need to adapt to climate change. The most appropriate way to adapt to climate change in the area as shown in this chapter is small grain production. Small grain production is the best strategy given that small grains are drought resistant and can withstand the hot temperatures in Zvishavane. However, despite this realization, an insignificant number of Zvishavane farmers are involved in small grain production. This is due to numerous barriers that have affected the smooth implementation of small grains. Such barriers are inclusive of the labor associated with small grain production, the challenge posed by the quelea birds, food preferences, low markets, and low extension services and government support. If nothing is done to mitigate these barriers, Zvishavane will continue to be a food insecure area. In this regard, the chapter highlighted possible interventions that can assist in helping farmers adopt small grains, which include the development of improved varieties, adoption of CSA practices, improved technical support, and access to markets. The labor intensiveness associated with small grain production requires technology and machinery that help in reducing manual labor. There is also need for policies promoting small grain production and processing to add value to small grains.

\section{References}

Aaron J (2012) A framework for the development of smallholder farmers through cooperative development. Directorate Co-operative and Enterprise Development Department: Agriculture, Forestry and Fisheries Republic Of South Africa. Available at: https://www.nda.agric.za/ doaDev/sideMenu/cooperativeandenterprisedevelopment/docs/FRAMEWORK-\%20OF\% 20SMALL\%20FARMERS\%20(2).pdf

Bang K, Sitango K (2003) Indigenous drought coping strategies and risk management in Papua New Guinea, Cgprt Monograph 43

Bhatt A, Singh V, Shrotria PK, Baskheti DC (2003) Coarse grains of Uttaranchal: ensuring sustainable food and nutritional security. Indian Farmer's Digest, Luchnow

Chisi (Undated) Sorghum and Millet Breeding In Southern Africa in Practice, Golden Valley Research Station, www.afripro.org.uk

Dube C (2008) The impact of Zimbabwe's Drought Policy On Sontala Rural Community In Matabeleland South Province, Msc Thesis, Department Of Geology, Geography And Environmental Studies, Stellenbosch University

FAO (1996) Rome declaration on world food security and world food summit plan of action. World food summit 13-17 November 1996, Rome

FAO (2006) Fertilizer use by crop in Zimbabwe. Rome, Italy

FAO (2007) Climate change and food security, in United Nations Joint Press Kit for Bali Climate Change Conference, December 3-14, 2007, Bali

FAO (2010) Climate-smart agriculture policies, Practices and Financing for Food Security, Adaptation and Mitigation. Rome, Italy. http://www.fao.org/docrep/013/i1881e/i1881e00.pdf 
Gbetibouo GA (2009) Understanding farmers' perceptions and adaptations to climate change and variability: the case of the Limpopo Basin, South Africa IFPRI discussion paper. International Food Policy Research Institute, Washington, DC, forthcoming

Government of Zimbabwe (GoZ) (2014) Zimbabwe's climate change response strategy. Government of Zimbabwe, Ministry of Environment, Water and Climate, Harare

Gukurume S (2013) Climate change, variability and sustainable agriculture in Zimbabwe's rural communities. Rus J Agric Soc Econ Sci 14(2):89-100

HLPE (2013) Investing in smallholder agriculture for food security: a report by the high level panel of experts on food security and nutrition. HPLE report no. 6. Food and Agriculture Organization, Rome

Integrated Phase Classification Acute Food Insecurity Analysis Zimbabwe (IPC) (2019) Integrated food security phase classification: evidence and standards for better food security and nutrition decisions. FAO, Rome

Intergovernmental Panel on Climate Change (IPCC) (2001) Climate change 2001: impacts, adaptation vulnerability. Contribution of working group II to the third assessment report of the intergovernmental panel on climate change. Unep/Wmo, Geneva

Intergovernmental Panel on Climate Change (IPCC) (2007) Climate change: synthesis report. Contributions of working groups I, II and III to the fourth assessment report of the intergovernmental panel on climate change. IPCC, Geneva

International Crops Research Institute for the Semi-Arid Tropics (ICRISAT) (2015) "Is conservation agriculture an option for vulnerable households?" Briefing note 4, September. ICRISAT. Bulawayo, Zimbabwe

de Jager A, Onduru D, Van Wijk MS, Vllaming J, Gachini GN (2001) Assessing sustainability of low-external input farm management systems with the nutrient monitoring approach: A case study in Kenya. Agric Syst 69:99-118

Jerie S, Ndabaningi T (2011) The impact of rainfall variability on rainfed tobacco in Manicaland province of Zimbabwe. J Sustain Dev Afr 13(1):241-250

Jiri O, Mafongoya P, Chivenge P (2015) Smallholder farmer perceptions on climate change and variability: a predisposition for their subsequent adaptation strategies. J Earth Sci Clim Change 6:277. https://doi.org/10.4172/2157-7617.1000277

Jones $\mathrm{S}$ (2011). How does a food systems approach elucidate the food insecurity of Inuit in Canada? Global Environmental Change and Food Systems, GECAFS Working Paper7. University of Oxford

Leuschner K Manthe CS (1996) Drought tolerant crops for Southern Africa. In: Proceedings of the SADC/ICRISAT regional sorghum and pearl millet workshop, 25-29 July 1994. Gaborone, Botswana

Louw A (2013) Sustainable policy support for smallholder agriculture in South Africa: key issues and options for consideration. In: Greenburg S (ed) Smallholder and agro-food value chains in South Africa. PLAAS, Bellville

Lowder SK, Skoet J, Raney T (2016) The number, size, and distribution of farms, smallholder farms, and family farms worldwide. World Dev 87:16-29

Maddison D (2006) The perception of and adaptation to climate change in Africa. CEEPA discussion paper no. 10. Centre for Environmental Economics and Policy in Africa, University of Pretoria

Mapfumo P, Mtambanengwe F, Giller KE, Mpepereki S (2005) Tapping indigenous herbaceous legumes for soil fertility management by resource-poor farmers in Zimbabwe. J Agric Ecosyst Environ 109:221-233. [Online]. Available from: http://www.sciencedirect.com

Mawere M Madziwa BF Mabeza CM (2013) Climate change and adaptation in third world Africa: a quest for increased food security in semi-arid Zimbabwe. Int J Human Soc Stud. Issn 23219203

Morton J (2007) The impact of climate change on smallholder and subsistence agriculture. PNAS 104:19680-19685 
Mugabe FT Hodnett M Senzanje A (2007) Comparative hydrological behaviour of two small catchments in semi-arid Zimbabwe. J Arid Environ. https://doi.org/10.1016/J.Jaridenv.2006. 11.016

Mugiya D, Hofisi C (2017) Climate change adaptation challenges confronting small scale farmers. Environ Econ 8(1):57-65. https://doi.org/10.21511/ee.08(1).2017.06

Mukarumbwa P, Mushunje A (2010) Potential of sorghum and finger millet to enhance household food security in Zimbabwe's semi-arid regions: a review, contributed paper presented at the joint 3rd African Association of Agricultural Economists (AAAE) and 48th Agricultural Economists Association of South Africa (AEASA) Conference, Cape Town, South Africa, September 1923, 2010

Musara JP, Musemwa L, Mutenje M, Mushunje A, Pfukwa C (2019) Determinants of sorghum adoption and land allocation intensity in the smallholder sector of semi-arid Zimbabwe. Span J Agric Res 17(1):E0105. https://doi.org/10.5424/Sjar/2019171-13115

Musara JP, Musemwa L (2020) Impacts of improved sorghum varieties intensification on household welfare in the mid-Zambezi Valley of Zimbabwe. Agrekon 59(2):254-267

Mutasa M (2011) Climate change vulnerability and adaptation in failing states: Zimbabwe's Drought struggle: Paper prepared for the Initiative on Climate Adaptation Research and Understanding through the Social Sciences (ICARUS-2) meeting at the University of Michigan (5-8 May 2011) themed, "Vulnerability and Adaptation: Marginal Peoples and Environments." Although there are several climate change-induced impacts, this paper focuses on drought, which poses a huge challenge in rural rain-fed agro-economies

Mutekwa VT (2009) Climate change impacts and adaptation in the agricultural sector: the case of smallholder farmers in Zimbabwe. J Sustain Dev Afr 11(2):237-256

Muzerengi T, Tirivangasi HM (2019) Small grain production as an adaptive strategy to climate change in Mangwe District, Matabeleland South in Zimbabwe. Jàmbá J Disaster Risk Stud 11(1):A652. https://doi.org/10.4102/Jamba.V11i1.652

Nciizah T (2014) The contribution of small grain production to food security in drought prone areas: the case of Zvishavane (2000-2014) A thesis Submitted in Fulfilment of the Requirements for the Degree of Master of Arts in Development Studies at Midlands State University

Nciizah E. (2019). Understanding climate change and rural livelihoods in Zimbbabwe: adaptation by communal farmers in Ngundu, Chivi District, A thesis Submitted in Fulfilment of the Requirements for the Degree of Doctor Philosophy of Rhodes University

Oakland Institute and The Alliance For Food Sovereignty In Africa (AFSA) (Undated). www. oaklandinstitute.org, www.afsaafrica.org

OCHA (2012) Midlands province - natural farming regions. http://ochaonline.un.org/zimbabwe

Okonya JS, Syndikus K, Kroschel J (2013) Farmers' perception of and coping strategies to climate change: evidence from six agro-ecological zones of Uganda. Received: OnlinePublished: July15, 2013. https://doi.org/10.5539/jas.v5n8p25

Orr A, Mwema C, Gierend A, Nedumaran S (2016) Sorghum and millets in Eastern and Southern Africa. Facts, trends and outlook. Working paper series no. 62. ICRISAT research program, markets, institutions and policies. Patancheru 502 324. International Crops Research Institute for the Semi-Arid Tropics, Telangana. $76 \mathrm{Pp}$

Rukuni M,Tawonezvi P, Eicher C, Munyuki-Hungwe M, Matondi P (2006) Zimbabwe's agricultural revolution revisited, University of Zimbabwe Publications. Harare, Zimbabwe

Sharma KK, Crouch JH, Seetharama N, Hash CT (2002) Applications of biotechnology for crop improvement: prospects and constraints. Vitro Cell Dev Biol—Plant 163:381-395

Simba F, Chikodzi D, Murwendo T (2012) Climate change scenarios, perceptions and crop production: a case study of semi-arid Masvingo province in Zimbabwe. J Earth Sci Clim Change 3:124. https://doi.org/10.4172/2157-7617.1000124

Sukume C, Makudze E, Mabeza-Chimedza R, Zitsanza N (2000) Comparative economic advantange of crop production in Zimbabwe. Technical paper no. 99 Department of Agricultural Economics and Extension. University of Zimbabwe, Harare 
Taylor JRN (2003). Overview importance of sorghum in Africa [Online]. Available from: http:// www.sciencedirect.com/science?

Taylor JR, Schober TJ, Bean S (2006). Novel and non-food uses for sorghum and millets. J Cereal Sci 44:252-271

The Chronicle (2020) Promotion of small grains pays dividends for farmers: Chronicle.co.zw

UNDP (2018a) Barrier analysis of small grains value chain in Zimbabwe, Technical Notes Series No. 3

UNDP (2018b) Emerging solutions in small grains value chain in Zimbabwe, Technical Notes Series No. 4

Zimbabwe Agricultural Sector Survey (2019) Edited by Mutenga T, The State of Zimbabwe's Agricultural Sector Survey 2019, Harare

Zimbabwe Vulnerability Assessment Committee (ZimVAC) Market Asseessment Report (2015) Food and Nutrition Council at SIRDC, Hatcliffe, Harare, Zimbabwe

Zimbabwe Vulnerabilty Assessment Committee (ZimVAC), Rural Livelihoods Assessment (2016) Food and Nutrition Council (FNC) at SIRDC, Hatcliffe, Harare, Zimbabwe

Open Access This chapter is licensed under the terms of the Creative Commons Attribution 4.0 International License (http://creativecommons.org/licenses/by/4.0/), which permits use, sharing, adaptation, distribution and reproduction in any medium or format, as long as you give appropriate credit to the original author(s) and the source, provide a link to the Creative Commons license and indicate if changes were made.

The images or other third party material in this chapter are included in the chapter's Creative Commons license, unless indicated otherwise in a credit line to the material. If material is not included in the chapter's Creative Commons license and your intended use is not permitted by statutory regulation or exceeds the permitted use, you will need to obtain permission directly from the copyright holder.

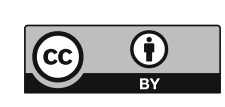

